
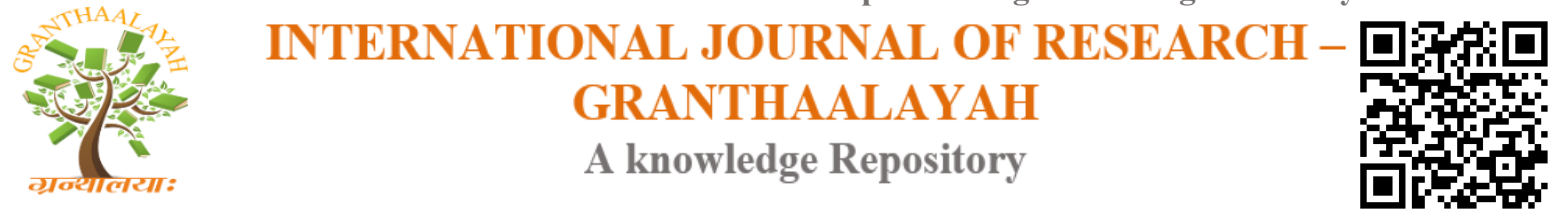

Management

\title{
ANALYSIS OF PRINCIPALS' MANAGEMENT ACTIVITIES FOR SUSTAINABLE QUALITY ASSURANCE IN SECONDARY SCHOOLS IN ANAMBRA STATE
}

\author{
Ugwu Ifeanyichukwu ${ }^{1}$, Dr. Oparaji Israel Chijiuka ${ }^{2}$, Mrs Chime Gladys O. ${ }^{3}$ \\ 1,2, ${ }^{3}$ Department of Educational Management and Policy, Nnamdi Azikiwe University, Awka
}

\begin{abstract}
The persistent decline in the quality of education in Nigeria in general and in Anambra state in particular gives serious cause for concern. Something has to be done about it and urgently too. This prompted the study to analyze principals' management activities for sustainable quality assurance in secondary schools in Anambra state. Two research questions guided the study and two hypotheses were tested. Descriptive survey research design was adopted for the study. The population of the study comprised all the 257 public secondary school principals in Anambra State. No sampling was done due to the relatively small size of the population of the study. A 21-item questionnaire titled “Analysis of Principals' Management Activities for Sustainable Quality Assurance Questionnaire (APMASQAQ)" was the instrument for data collection. The instrument was subjected to face validation by three experts from Faculty of Education, NnamdiAzikiwe University. Cronbach alpha method was used to ascertain the reliability of the instrument. The overall coefficient of 0.84 was obtained. Mean was used to answer the research questions, while Z-test was used to test the null hypotheses at 0.05 level of significance. The findings of the study, among others revealed that principals' students' academic performance monitoring activities for sustainable quality assurance in secondary schools in Anambra state was low. It also revealed that there was no significant difference in the mean ratings of male and female principals on the extent of their engagement in management activities for sustainable quality assurance in secondary schools in Anambra State. Based on the findings it was recommended among others that principals should encourage the teachers to take the continuous assessment exercise very serious and also make provisions for learners with special learning needs to bring about all inclusive learning.
\end{abstract}

Keywords: Sustainable; Management; Anambra State.

Cite This Article: Ugwu Ifeanyichukwu, Dr. Oparaji Israel Chijiuka, and Mrs Chime Gladys O.. (2020). "ANALYSIS OF PRINCIPALS' MANAGEMENT ACTIVITIES FOR SUSTAINABLE QUALITY ASSURANCE IN SECONDARY SCHOOLS IN ANAMBRA STATE." International Journal of Research - Granthaalayah, 8(1), 294-304. 


\section{Introduction}

Everywhere in the world Nigeria inclusive public discussions on education are frequently focused on the need for quality assurance sustainability. The reason is obvious- no Nation can develop beyond the level of development in her education industry. More so, for improved living standard, wealth creation, better living conditions of the people, education remains the only way to go.

The momentum of quality assurance in education in secondary schools expectedly should come from the principals and this should come in the form of regular school self-evaluation and academic performance monitoring activities for both students and teachers; ensuring that students are on track and that teaching and learning is consistently in line with government's policy expectations on secondary education.

The students for whose interest the school exist have to be properly monitored to ensure that consistent progress is made in their academic performance. This according to Federal Ministry of Education (2010 pp21) can be achieved by:

1) Providing diagnostic services to help students discover their abilities, aptitudes and objectives.

2) Supervising, evaluating and developing the co-curricular activities of students and

3) Keeping a cumulative record of information about the students and making same available to the proper persons among others.

Schools can also make progress through regular self-evaluation. Self-evaluation is crucial in supporting the school in its quest to improve the quality of education for learners in its care. It also, helps the school to identify and focus on areas where improvement in their provision needs to be made. Federal Ministry of Education (2010 pp22.) identified three key ways of conducting school self-evaluation. They are:

1) Diagnosing precisely where the strengths and weaknesses lie and implication for necessary change;

2) Identifying the key priorities; and

Meanwhile, some scholars have argued that male principals are better school administrators than their female counterparts. But another school of thought subscribe to the contrary. Matheri (2015) for instance, submitted that there is no significant relationship between the principals' gender and their effectiveness in management of personnel, students and finance of their schools. Quality assurance in secondary schools is enhanced through regular self-evaluation and effective students' academic performance monitoring by the principals, their gender notwithstanding.

Over the years, the mode of secondary school inspection in Nigeria has not provided the desired effect on quality assurance in secondary schools. It had been largely diagnostic, lacked the laws to apply appropriate sanctions on erring proprietors and school managers and devoid of uniform management practices and guidelines to be adopted by schools (FME, 2010). Worried by this trend, the Federal Ministry of Education through the federal Inspectorate Services and States Inspectorates in 2009 produced the "Quality Assurance Instrument for Basic and Secondary Education in Nigeria" to engender and sustain quality in the education enterprise. The instrument is expected to help secondary schools to constantly improve on their performance. The instrument 
was first published in 2009 and launched in 2010 for domestication by states Ministries of Education. Anambra state is one of the states that have domesticated this policy.

Anambra state has been rated very high in West African Senior Secondary Certificate Examination (WASSCE) and National Examination Council (NECO) in recent times but there are still several indicators of low quality in secondary schools in the aspects of regular self-evaluation and academic performance monitoring which if not properly handled, have the potency of compromising the quality and standard of secondary education in the state. Ikediugwu and Chukwumah (2015) noted that the challenges facing secondary schools in Anambra state have been those of poor infrastructure, inadequate staffing, inadequate funding, poorly motivated students and poor quality assurance practices owing to various training limitations (e.g. lack of regular self-evaluation, students' academic performance monitoring among others.) More so, Maduemezie (2015) asserted that Anambra state like every other states in Nigeria has had its fair share of examination malpractice. Maduemezie further stressed that schools that engage in this act, lose the essence of producing students who will become productive members of their society. There is therefore, the need to mitigate these indices of low quality assurance empirically. Hence, aim of this study was to analyse the principals' management activities for sustainable quality assurance in secondary schools in Anambra state.

\section{Statement of the Problem}

Sustainable quality secondary education is necessary for the development of students' potentials abilities and necessary skills for continuous development and survival of Anambra State. Principals as the chief executives of secondary schools are responsible for directing, stimulating monitoring and evaluating both the staff and students activities to enhance the delivery of improved secondary education. Available literature and observation by the authors would suggest that secondary schools principals in Anambra State are not operating optimally in terms of students' academic performance monitoring and regular self-evaluation; the persistence of examination malpractice, truancy among staff and students, poor attitude to work among others as observed by the researchers in some secondary schools in Anambra State leave much to be desired. As a result, students are not likely to acquire the needed skills, knowledge and competencies to develop their potentials that would bring about positive development and sustainable growth in terms of quality assurance in education in Anambra State.

\section{Purpose of the Study}

The main purpose of this study was to analyze the principals' management activities for sustainable quality assurance in secondary schools in Anambra state.

Specifically, the study analyzed the principals':

1) School self-evaluation activities for sustainable quality assurance in secondary schools in Anambra State.

2) Students' academic performance monitoring activities for sustainable quality assurance in secondary in Anambra State. 


\section{Research Questions}

The following research questions guided the study; what is the extent of principals'

1) School self-evaluation activities for sustainable quality assurance in secondary schools in Anambra State?

2) Students' academic performance monitoring activities for sustainable quality assurance in secondary schools in Anambra State?

\section{Hypotheses}

The following null hypotheses were tested at 0.05 level of significance:

1) There is no significant difference in the mean ratings of male and female principals on the extent of their engagement in school self-evaluation activities for sustainable quality assurance in secondary schools in Anambra State.

2) There is no significant difference in the mean ratings of male and female principals on the extent of their engagement in academic performance monitoring activities of students for sustainable quality assurance in secondary schools in Anambra State.

\section{Method}

The study adopted the descriptive survey research design. According to Nworgu (2015), descriptive research design aims at collecting data on, describing and assessing in a systematic manner the characteristics, features or facts about a given population. The design was found appropriate for the study because principals' management activities are existing characteristics, features and facts in secondary schools in Anambra State. Therefore, the researcher collected data from principals on the extent of their engagement in management activities for sustainable quality assurance in secondary schools in Anambra State.

The study was conducted in AnambraState. The State has twenty-one Local Government Area with 257 public secondary schools. The state is one of the five states in south-east geopolitical zone of Nigeria with six education zones namely:Aguata, Awka, Nnewi, Ogidi, Onitsha, and Otuocha. The state shares boundaries with Delta and Rivers in theWest, kogi and Enugu in the North, Abia and Imo in the East.The State Post Primary School Service Commission at Awka centrally controls the senior secondary schools. The inhabitants of Anambra State are mainly traders, civil servants and farmers in the rural areas. Anambra state is notable for great enthusiasm and huge investment in education hence the researcher deemed it apt to undertake this study in the state.

The population of the study is made up of 257 respondents comprising 257 principals of public secondary schools in Anambra state. The population distribution of public secondary school principals by education zone are: Aguata52, Awka61, Nnewi48, Ogidi39, Onitsha 31 and Otuocha 26. The above data were as collected from Post Primary School Service Commission Awka,2019. All the 257 principals were used for the study. Hence, no sampling was done because of the small size of the population.

The instrument used to elicit information from the respondents is researchers' designed questionnaire titled "Analysis of Principals' Management Activities for sustainable Quality 
Assurance in Secondary Schools Questionnaire"(APMASQA).The instrument has section A which is for the respondents' gender while section B contains items developed by the researcher in line with the research questions and hypotheses. Section B is divided into 2 parts. Partlcontains items on academic performance monitoring activities of principals for sustainable quality assurance in secondary school while part 2 contains items on school self-evaluation activities of principals for sustainable quality assurance in secondary school. The items are structured on a four-point scale of "Very High Extent (VHE), High Extent (HE), Low Extent (LE) and Very Low Extent (VLE) weighted 4,3,2 and 1 respectively.

The instrument was subjected to face validation using three experts who are lecturers; two from Educational Management and one from Measurement and Evaluation from the Departments of Educational Management and Policy and Educational Foundations respectively all in the Faculty of Education, Nnamdi Azikiwe University, Awka. Copies of the questionnaire were given to the experts alongside the purpose of the study, research questions and hypotheses to guide them. They were requested to check the appropriateness of the items in the instruments in achieving the purpose of the study and answering the research questions. They thus reviewed the questionnaire items for clarity and appropriateness and made inputs and corrections. Some items in the original instruments were dropped while entirely new items were developed in line with the valuators' expert suggestions.

To establish the reliability of the instrument, twenty four public secondary schools were sampled using simple random sampling technique from Enugu state which is not part of the population of the study. Twenty four principals of the sampled schools were used. Copies of the questionnaire were administered on them. Cronbach alpha method was used to determine the internal consistency of the items. The reliability coefficients for the two parts of the instrument were 0.84 and 0.85 respectively, while the overall reliability coefficient of the instrument was 0.84.In line with Fraenkel and Wallen, (2000) who maintained that items will be considered reliable and desirable for consistency level if they yield a reliability coefficient of 0.70 and above, the instrument was considered reliable for the study.

Two hundred and fifty-seven (257) copies of the questionnaire were administered to the respondents by the researcher with the help of six research assistants. The research assistants were post-graduate students of Department of Educational Management and Policy, Faculty of Education, NnamdiAzikiwe University. They are suitable as they have been exposed to the rudiments of research. To further enhance their performance, they were briefed by the researcher on the nature of the study including the purpose of the study. This was to ensure that they have a good knowledge of the study and this helped them to answer questions and make clarifications that the respondents demanded from them in the course of data distribution and collection. Direct approach method of distribution was employed. Two hundred and forty two (242) copies of the questionnaire that were distributed were properly filled and retrieved indicating $94 \%$ return rate. The research questions were answered using mean statistics and standard deviation, while the hypotheses were tested using t-test. There was need for the opinions of all the principals that participated in this study to be considered, hence, Mean statistics was used because by the very nature of the way in which mean is computed, it takes into account, or is based on, each and every participant's score, so that the scores of each participants count. Male and female principals were the groups that participated in this study so, t-test was used because t-test, determines whether the 
means of two groups are significantly different at a selected probability level. In answering the research questions in this study, mean between: 4.00-3.50, 3.49-2.50, 2.49-1.50, and 1.49-below were taken to indicate: VHE, HE, LE, VLE respectively. In testing the null hypotheses, when tcalculated is less than t-critical at 0.05 level of significance and degree of freedom, the null hypotheses was not rejected but when $\mathrm{t}$-calculated is equal to or greater than the t-critical, it was rejected.

\section{Results}

Research Question 1: What is the extent of principals' academic performance monitoring activities for sustainable quality assurance in secondary schools in Anambra State?

Table 1: Mean Ratings and Standard Deviation on Male and Female Principals' Academic Performance Monitoring Activities for Sustainable Quality Assurance in Secondary Schools in Anambra State.

\begin{tabular}{|c|c|c|c|c|c|c|c|c|c|c|}
\hline \multirow[t]{2}{*}{$\mathbf{S} / \mathbf{N}$} & \multirow[t]{2}{*}{ Items } & \multicolumn{3}{|c|}{$\begin{array}{l}\text { Male Principals } \\
\quad(\mathbf{N}=\mathbf{1 1 3})\end{array}$} & \multicolumn{3}{|c|}{$\begin{array}{l}\text { Female Principals } \\
(\mathbf{N}=129)\end{array}$} & \multicolumn{3}{|c|}{ Total $(N=242)$} \\
\hline & & Mean & Sd & Remark & Mean & Sd & Remark & Mean & Sd & Remark \\
\hline 1 & $\begin{array}{l}\text { Observe and } \\
\text { analyze school } \\
\text { records } \\
\text { (examination } \\
\text { results) for } \\
\text { improvement }\end{array}$ & 2.17 & 1.07 & $\begin{array}{c}\text { Low } \\
\text { Extent }\end{array}$ & 2.23 & 1.11 & $\begin{array}{c}\text { Low } \\
\text { Extent }\end{array}$ & 2.21 & 1.10 & $\begin{array}{c}\text { Low } \\
\text { Extent }\end{array}$ \\
\hline 2 & $\begin{array}{l}\text { Monitoring the } \\
\text { continuous } \\
\text { assessment } \\
\text { exercise of the } \\
\text { students to } \\
\text { encourage } \\
\text { students' } \\
\text { participation in } \\
\text { all the school } \\
\text { programmes }\end{array}$ & 2.13 & 1.06 & $\begin{array}{l}\text { Low } \\
\text { Extent }\end{array}$ & 2.20 & .99 & $\begin{array}{l}\text { Low } \\
\text { Extent }\end{array}$ & 2.18 & 1.01 & $\begin{array}{c}\text { Low } \\
\text { Extent }\end{array}$ \\
\hline 3 & $\begin{array}{l}\text { Observing the } \\
\text { teachers during } \\
\text { lecture delivery } \\
\text { to ensure that the } \\
\text { curriculum } \\
\text { contents are } \\
\text { covered }\end{array}$ & 2.60 & 1.11 & $\begin{array}{l}\text { High } \\
\text { Extent }\end{array}$ & 2.72 & 1.07 & $\begin{array}{l}\text { High } \\
\text { Extent }\end{array}$ & 2.68 & 1.08 & $\begin{array}{l}\text { High } \\
\text { Extent }\end{array}$ \\
\hline 4 & $\begin{array}{l}\text { Supervising and } \\
\text { monitoring } \\
\text { students' } \\
\text { responses during } \\
\text { lesson delivery } \\
\text { to find out those }\end{array}$ & 2.67 & 1.14 & $\begin{array}{l}\text { High } \\
\text { Extent }\end{array}$ & 2.72 & 1.07 & $\begin{array}{l}\text { High } \\
\text { Extent }\end{array}$ & 2.70 & 1.10 & $\begin{array}{l}\text { High } \\
\text { Extent }\end{array}$ \\
\hline
\end{tabular}




\begin{tabular}{|c|c|c|c|c|c|c|c|c|c|c|}
\hline & $\begin{array}{l}\text { that need extra } \\
\text { attention }\end{array}$ & & & & & & & & & \\
\hline 5 & $\begin{array}{l}\text { Making } \\
\text { provision for } \\
\text { learners with } \\
\text { special needs to } \\
\text { bring about all } \\
\text { inclusive } \\
\text { learning }\end{array}$ & 1.86 & .86 & $\begin{array}{l}\text { Low } \\
\text { Extent }\end{array}$ & 2.06 & .99 & $\begin{array}{l}\text { Low } \\
\text { Extent }\end{array}$ & 1.99 & .95 & $\begin{array}{l}\text { Low } \\
\text { Extent }\end{array}$ \\
\hline 6 & $\begin{array}{l}\text { Interacting with } \\
\text { learners in their } \\
\text { language of } \\
\text { instruction to } \\
\text { find out how } \\
\text { they are coping } \\
\text { with their } \\
\text { language of } \\
\text { instruction for } \\
\text { the purpose of } \\
\text { adjustment if } \\
\text { need be }\end{array}$ & 2.38 & 1.01 & $\begin{array}{l}\text { Low } \\
\text { Extent }\end{array}$ & 2.20 & 1.01 & $\begin{array}{l}\text { Low } \\
\text { Extent }\end{array}$ & 2.26 & 1.05 & $\begin{array}{l}\text { Low } \\
\text { Extent }\end{array}$ \\
\hline 7 & $\begin{array}{l}\text { Scrutinize } \\
\text { learners' work in } \\
\text { exercise books } \\
\text { and ensures they } \\
\text { conform to } \\
\text { expectations and } \\
\text { set standards }\end{array}$ & 1.90 & .99 & $\begin{array}{l}\text { Low } \\
\text { Extent }\end{array}$ & 2.25 & .99 & $\begin{array}{l}\text { Low } \\
\text { Extent }\end{array}$ & 2.13 & 1.07 & $\begin{array}{l}\text { Low } \\
\text { Extent }\end{array}$ \\
\hline & Mean of means' & 2.24 & 1.03 & $\begin{array}{c}\text { Low } \\
\text { Extent }\end{array}$ & 2.34 & .88 & $\begin{array}{c}\text { Low } \\
\text { Extent }\end{array}$ & 2.31 & 1.05 & $\begin{array}{c}\text { Low } \\
\text { Extent }\end{array}$ \\
\hline
\end{tabular}

Table1 revealed that items 1, 2 and 3-5 fall within the range of 1.50-2.49 indicating that the extent of male and female principals' compliance with the items was low. Items 6 and 7 fall within the range of 2.50-3.49 indicating high extent of male and female principals' compliance with the items.The standard deviations of 1.03 and .88 for male and female principals respectively indicate a non- significant difference of .15 which implies almost the same amount of disparity from the mean scores. The mean of means' scores of 2.24 and 2.34 of male and female principals respectively as well as the general mean of means' of 2.31 which falls within the range of 1.502.49 indicates low extent of principals' engagement in students' academic performance monitoring activities for sustainable quality assurance in secondary schools in Anambra state.

Research Question 2: What is the extent of principals' school self-evaluation activities for sustainable quality assurance in secondary school in Anambra State? 
Table 2: Mean Ratings and Standard Deviations on Male and Female Principals' School Selfevaluation activities for sustainable quality assurance in Secondary Schools in Anambra State.

\begin{tabular}{|c|c|c|c|c|c|c|c|c|c|c|}
\hline \multirow[t]{2}{*}{$\mathbf{S} / \mathbf{N}$} & \multirow[t]{2}{*}{ Items } & \multicolumn{3}{|c|}{$\begin{array}{l}\text { Male Principals } \\
(\mathbf{N}=113)\end{array}$} & \multicolumn{3}{|c|}{$\begin{array}{c}\text { Female Principals } \\
(\mathbf{N}=129)\end{array}$} & \multicolumn{3}{|c|}{ Total $(\mathrm{N}=242)$} \\
\hline & & Mean & Sd & Remark & Mean & Sd & Remark & Mean & Sd & Remark \\
\hline 8 & $\begin{array}{l}\text { Reviewing the } \\
\text { school } \\
\text { professional } \\
\text { development } \\
\text { programme of } \\
\text { teachers to see } \\
\text { how they } \\
\text { contribute to } \\
\text { improvement in } \\
\text { the discharge of } \\
\text { their duties }\end{array}$ & 2.03 & .84 & $\begin{array}{c}\text { Low } \\
\text { Extent }\end{array}$ & 2.14 & .69 & $\begin{array}{c}\text { Low } \\
\text { Extent }\end{array}$ & 2,11 & 1.00 & $\begin{array}{c}\text { Low } \\
\text { Extent }\end{array}$ \\
\hline 9 & $\begin{array}{l}\text { Examining } \\
\text { learners' view } \\
\text { about the quality } \\
\text { of education they } \\
\text { receive for } \\
\text { necessary } \\
\text { improvement }\end{array}$ & 2.11 & 1.07 & $\begin{array}{l}\text { Low } \\
\text { Extent }\end{array}$ & 2.33 & .69 & $\begin{array}{l}\text { Low } \\
\text { Extent }\end{array}$ & 2.26 & 1.08 & $\begin{array}{l}\text { Low } \\
\text { Extent }\end{array}$ \\
\hline 10 & $\begin{array}{l}\text { Examining } \\
\text { parents opinion } \\
\text { about the quality } \\
\text { of education } \\
\text { their children } \\
\text { receive for } \\
\text { necessary } \\
\text { improvement }\end{array}$ & 2.30 & 1.11 & $\begin{array}{l}\text { Low } \\
\text { Extent }\end{array}$ & 2.39 & .69 & $\begin{array}{l}\text { Low } \\
\text { Extent }\end{array}$ & 2.36 & 1.09 & $\begin{array}{l}\text { Low } \\
\text { Extent }\end{array}$ \\
\hline 11 & $\begin{array}{l}\text { Considering the } \\
\text { view of other } \\
\text { stakeholders in } \\
\text { education eg. } \\
\text { School based } \\
\text { management } \\
\text { committee on the } \\
\text { quality of } \\
\text { education } \\
\text { provided by the } \\
\text { school for } \\
\text { improvement of } \\
\text { learning } \\
\text { experience }\end{array}$ & 2.61 & 1.11 & $\begin{array}{l}\text { High } \\
\text { Extent }\end{array}$ & 2.75 & .93 & $\begin{array}{l}\text { High } \\
\text { Extent }\end{array}$ & 2.70 & 1.14 & $\begin{array}{l}\text { High } \\
\text { Extent }\end{array}$ \\
\hline 12 & $\begin{array}{l}\text { Examining the } \\
\text { rate of } \\
\text { development of } \\
\text { the school so as } \\
\text { to make }\end{array}$ & 2.16 & 1.07 & $\begin{array}{l}\text { Low } \\
\text { Extent }\end{array}$ & 2.27 & 1.17 & $\begin{array}{l}\text { Low } \\
\text { Extent }\end{array}$ & 2.23 & 1.07 & $\begin{array}{l}\text { Low } \\
\text { Extent }\end{array}$ \\
\hline
\end{tabular}




\begin{tabular}{|c|c|c|c|c|c|c|c|c|c|c|}
\hline & $\begin{array}{l}\text { necessary } \\
\text { adjustment for } \\
\text { improvement }\end{array}$ & & & & & & & & & \\
\hline 13 & $\begin{array}{l}\text { Examining } \\
\text { schools' } \\
\text { achievements } \\
\text { over a period of } \\
\text { time to serve as } \\
\text { encouragement } \\
\text { for better } \\
\text { performance }\end{array}$ & 2.17 & 1.10 & $\begin{array}{c}\text { Low } \\
\text { Extent }\end{array}$ & 2.21 & .59 & $\begin{array}{l}\text { Low } \\
\text { Extent }\end{array}$ & 2.20 & 1.10 & $\begin{array}{l}\text { Low } \\
\text { Extent }\end{array}$ \\
\hline 14 & $\begin{array}{l}\text { Considering the } \\
\text { school target for } \\
\text { teachers to see } \\
\text { how well they } \\
\text { meet up with } \\
\text { their expectation }\end{array}$ & 2.34 & 1.08 & $\begin{array}{c}\text { Low } \\
\text { Extent }\end{array}$ & 2.25 & .81 & $\begin{array}{c}\text { Low } \\
\text { Extent }\end{array}$ & 2.28 & 1.10 & $\begin{array}{c}\text { Low } \\
\text { Extent }\end{array}$ \\
\hline 15 & $\begin{array}{l}\text { Considering the } \\
\text { school target for } \\
\text { learners to see } \\
\text { how well they } \\
\text { have been } \\
\text { achieved }\end{array}$ & 1.98 & 1.04 & $\begin{array}{c}\text { Low } \\
\text { Extent }\end{array}$ & 2.32 & & $\begin{array}{l}\text { Low } \\
\text { Extent }\end{array}$ & 2.20 & 1.03 & $\begin{array}{c}\text { Low } \\
\text { Extent }\end{array}$ \\
\hline & Mean of means' & 2.21 & 1.01 & $\begin{array}{c}\text { Low } \\
\text { Extent }\end{array}$ & 2.33 & 1.06 & $\begin{array}{l}\text { Low } \\
\text { Extent }\end{array}$ & 2.27 & 1.08 & $\begin{array}{c}\text { Low } \\
\text { Extent }\end{array}$ \\
\hline
\end{tabular}

Table 2 revealed that items8-10 and 12-15 fall within the range of 1.50-2.49 indicating that the extent male and female principals' compliance with the items was low. Item 11 with mean score of 2.70, falls within the range of (2.50-3.49) indicating high extent of male and female principals' compliance with the item. The standard deviations of 1.01 and 1.06 for male and female principals respectively indicate convergence and closer disparity from the mean scores. The mean of means' scores of 2.21 and 2.33 of male and female principals respectively as well as the general mean of means' of 2.27 which falls within the range of 1.50-2.49 indicates that the extent of principals' engagement in school self-evaluation activities for sustainable quality assurance in secondary schools in Anambra state was low.

\section{Discussion of Findings}

The research question one and null hypothesis one, focused on principals' engagement in monitoring of students' academic performance activities for sustainable quality assurance. The result of data analyzed in table 1 revealed that there is low extent of principals' engagement in monitoring of students' academic performance activities for sustainable quality assurance in Anambra state. This finding is in agreement with Ndungu (2015) who found out that the extent of principals' effectiveness in students' monitoring and evaluation is low. The null hypothesis 1 in table 3 shows that there is no significant difference in the mean ratings of male and female principals on the extent of their engagement in academic performance monitoring activities for sustainable quality assurance in secondary schools in Anambra state. This finding is in line with 
the finding of Ogor (2007) who found out that there was no significant gender difference in the performance of principals on students' academic performance monitoring. This implies among other things that principals in Anambra state irrespective of their gender engage in academic performance monitoring activities for sustainable quality assurance to a low extent.

The result of data analyzed in table 2 revealed that there is low extent of principals' engagement in self-evaluation activities for sustainable quality assurance in Anambra state. This finding was alluded to by Kokeyo and Oluochi (2015) who reported that most secondary schools in Tanzania depend largely on external inspection for schools improvement and quality assurance and as such engage in school self-evaluation practices to a low extent. The null hypothesis 2 in table 4 shows that there is no significant difference in the mean ratings of male and female principals on the extent their engagement in school self-evaluation activities in secondary schools in Anambra state. This is in contrast with the finding of Carr (1988) in Sardarzahi (2015) who found out that male and female principals of high schools have different views on the extent to which they conduct school self-appraisal for quality assurance. The contradiction in the findings of the two studies may be accounted for by difference in training, experience and qualifications of male and female principals that were studied. This therefore implies that the gender of principals significantly affects the extent of their engagement in school self-evaluations activities for sustainable quality assurance.

\section{Conclusion}

Based on the findings of this study, it was concluded that there is low extent of principals' engagement in management activities sustainable for quality assurance in secondary schools in Anambra state. This implies that there was low extent of principals' engagement in academic performance monitoring and self evaluation activities for sustainable quality assurance in secondary schools in Anambra State.

\section{Recommendations}

Based on the findings of this study, it was recommended among others that:

1) Principals should encourage the teachers to take the continuous assessment exercise very serious and also make provisions for learners with special learning needs to bring about all inclusive learning.

2) Principal and teachers alike should from time to time examine the learners' view about the quality of education they receive for necessary adjustment and improvement.

\section{References}

[1] Federal Ministry of Education, (2010). Quality assurance instrument for basic and secondary education In Nigeria. Abuja: NERDC

[2] Frankel, J. R. \&Wallen, N. E. (2000). How to design in education. New York: Longman Publishers

[3] Ikediugwu, N. P. \& Chukwumah, F. O. (2015). Strategic plan implementation and monitoring in secondary schools in Anambrastate. Greener Journal of Educational Research, 5(2), 17-26.

[4] Kokeyo, M. \& Oluoch, C. (2015). Self-Evaluation: a case study of a school in Dar Es Salaam Tanzania. Journal of Education and practice, 6(21) 88-102 
[5] Maduabuchi, M. A. (2002). Occupational stress factors among secondary school principals in Abia State, Nigeria. International Journal of Educational Planning and Administration, 1(1), 1727.

[6] Matheri, E.W. (2015). Principals' gender and management effectiveness in secondary schools. Journal of education and practice, 6(14) 23-35

[7] Ndungu, M. (2015). Influence of Monitoring and Evaluation by Principals on Effective Teaching and Learning in Public Secondary Schools in Nigeria. Journal of Education and Practice, 6(9), 145157

[8] Nworgu, B.G. (2015). Educational Research: Basic issues and methodology (3rd ed.). Enugu: University Trust Publishers.

*Corresponding author.

E-mail address: i.ugwu@unizik.edu.ng/israeloparaji@yahoo.com/begladinthelord0@gmail.com 